\title{
Proposals for copyright law and education during the COVID-19 pandemic
}

\author{
EMILY HUDSON* \\ King's College London \\ and \\ PAUL WRAGG** \\ University of Leeds
}

\begin{abstract}
This article asks whether the catastrophic impact of the COVID-19 pandemic justifies new limitations or interventions in copyright law so that UK educational institutions can continue to serve the needs of their students. It describes the existing copyright landscape and suggests ways in which institutions can rely on exceptions in the Copyright, Designs and Patents Act 1988 (CDPA), including fair dealing and the exemption for lending by educational establishments. It then considers the viability of other solutions. It argues that issues caused by the pandemic would not enliven a public interest defence to copyright infringement (to the extent this still exists in UK law) but may be relevant to remedies. It also argues that compulsory licensing, while permissible under international copyright law, would not be a desirable intervention, but that legislative expansion to the existing exceptions, in order to encourage voluntary collective licensing, has a number of attractions. It concludes by observing that the pandemic highlights issues with the prevailing model for academic publishing and asks whether COVID may encourage universities to embrace in-house and open access publishing more swiftly and for an even greater body of material.
\end{abstract}

Keywords: copyright; fair dealing; public interest; open access; online learning; universities; education; COVID-19.

\section{Background}

Tn this article, we discuss the relationship between copyright and education in light of the ICOVID-19 pandemic. Our focus is on higher education in the UK, although many of our ideas will be relevant to primary and secondary education, and to education in other countries. Our research question is simple: does the catastrophic impact of COVID justify state intervention so that educational institutions can continue to serve the needs of their students?

Although the COVID pandemic is often described as unprecedented, the copyrightrelated challenges it poses are not new but reflect longstanding questions about the goals and appropriate scope of copyright. Thus, we have for many years debated the sort of accommodations that should be made in copyright law to support education, given the

Reader in Law, The Dickson Poon School of Law, King's College London.

** Associate Professor of Law, School of Law, University of Leeds. The authors wish to acknowledge the extremely useful comments of the two anonymous reviewers, and thank Tanya Aplin, Robert Burrell, Chris Morrison and Jane Secker for their thoughts and feedback. 
high use of copyright works in teaching and learning but the problems in leaving every such use to one-on-one rights negotiation. ${ }^{1}$ Different countries have embraced different solutions, including free exceptions, compulsory licences and state-sanctioned mechanisms to encourage voluntary blanket licensing. With growth in the use of digital technologies in education, it has been asked whether reform is necessary. ${ }^{2}$ In the Directive on Copyright in the Digital Single Market (DSM Directive), for example, a mandatory exception for education was introduced in response to the concern that there is uncertainty regarding the application of existing exceptions and limitations to digital and online uses. ${ }^{3}$

The COVID pandemic has produced a more extreme and urgent version of the existing situation. It has necessitated two changes at educational institutions that are of particular relevance to this article: first, the closure of libraries, meaning that staff and students cannot access physical holdings and are entirely reliant on their library's virtual collection; and second, the need to move teaching and assessment online. As noted above, the copyright issues revealed by these changes are not new. However, the ramifications are more profound because certain in-person solutions are not available. To illustrate, for books not held in digital form, students cannot read the physical copy in the library. ${ }^{4}$ Lecturers cannot play audio-visual content in class but exclude that content from any lecture recording. ${ }^{5}$ In addition, with many universities planning to modify their teaching so that students can study remotely (and perhaps from outside the UK) for all or part of the 20/21 academic year, we need to plan for a lengthy period in which many of our students might never set foot in a library or a classroom, even if such spaces have reopened. 6

1 See generally E Hudson, ‘The Georgia State litigation: literal copying in education' (2019) 82 Modern Law Review 508. Copying by educational establishments and libraries was a significant focus of the Whitford Committee: see Committee to Consider the Law on Copyright and Designs, Report on Copyright and Designs Law (Cmnd 6732, 1977) (Whitford Report). Before that, the Gregory Committee also considered copying for students in its analysis of fair dealing: see Copyright Committee, Report of the Copyright Committee (Cmnd 8662, 1952). The Berne Convention for the Protection of Literary and Artistic Works (Berne Convention) has since its inception dealt with education in (what is now) Article 10(2): see S Ricketson and J Ginsburg, International Copyright and Neighbouring Rights: The Berne Convention and Beyond, volume I (2nd edn, Oxford University Press 2006), [13.44]-[13.45].

2 This expansion to the debate to consider digital technologies can be traced back a number of decades: see eg House of Representatives (Parliament of Australia), Copyright Amendment (Digital Agenda) Bill 1999: Explanatory Memorandum (1998-1999) 6 (goals of reform include to ensure that educational institutions, amongst others, 'have reasonable access to copyright material in the online environment'); K Crews, 'Distance education and copyright law: the limits and meaning of copyright policy' (2000) 27 Journal of College and University Law 15; J Secker, Copyright and E-learning: A Guide for Practitioners (Facet Publishing 2010) (a second edition was published in 2016, co-authored with C Morrison).

3 Directive (EU) 2019/790 of the European Parliament and of the Council of 17 April 2019 on copyright and related rights in the Digital Single Market and amending Directives 96/9/EC and 2001/29/EC, Recital 19. This exception is contained in Article 5.

4 Reading a physical book in the library does not implicate any of the restricted rights of the copyright owner in sections $16-21$ of the CDPA.

5 Playing a film in class may fall under the limitation in CDPA, section 34 which brings that act outside of the public performance right in section 19 . However, if playing a film to students online implicates any of the restricted rights of the copyright owner, it will be the communication right in section 20, which is not caught by section 34. In Section 2 of this article, we discuss the legal analysis behind this statement and ask whether educators might instead turn to fair dealing for the purpose of illustration for instruction in section 32. But for now the point is that the copyright situation is clearer for in-classroom than for online use.

6 In saying this, we appreciate that many of our students will never visit a library even in normal conditions. Importantly, while for some this may reflect preferences regarding how to allocate their time (ie on pursuits beyond their academic studies), other students are highly reliant on online collections for other reasons, including disability, care responsibilities, work commitments and living arrangements. 
Over the last few months, individuals from the UK education sector have articulated a number of concerns about the copyright impact of COVID. $^{7}$ One set of concerns revolve around pricing models for electronic content, for instance the huge discrepancies that can exist between buying the same book in hard copy and electronic form, and that publishers seem to be using price to encourage institutions to purchase aggregated access rather than individual items. ${ }^{8}$ A second set of concerns relate to print items for which there is no digital version, such that institutions will need to digitise those items themselves if they require an electronic version. While many issues are logistical (for instance regarding staff access to the library and the resource-intensiveness of scanning), there are concerns that many copying requests will exceed the quantities permitted under the blanket licence with the Copyright Licensing Agency (CLA) and will not be caught by a free exception. ${ }^{9}$ Third, there have been repeated questions about the use of audio-visual content given the complexity of rights in such material and the lack of a blanket licence (the nearest licence relating to broadcasts). ${ }^{10}$ Finally, it has been asked whether copyright strategies that were devised for in-person classes can apply to equivalent teaching taking place online, including to students in other countries.

In this article we start in Section 2 by describing the prevailing copyright landscape. In presenting this material, one of our aims is to emphasise flexibilities in the existing system, especially under fair dealing. We then consider other possible accommodations, beginning in Section 3 with an expanded role for public interest arguments. We focus first on the public interest defence, which industry representatives have identified as a potential mechanism to give educational institutions greater scope to carry out unremunerated copying. ${ }^{11}$ We identify a number of difficulties with this proposal,

7 See generally J Secker and C Morrison, 'Will the pandemic force universities to address the challenges of copyright?' (Wonkhe, Comment, 16 June 2020) <https://wonkhe.com/blogs/will-the-pandemic-forceuniversities-to-address-the-challenges-of-copyright-2/>.

8 See eg A Vernon, 'During this crisis, publishers must allow greater access to their content', Times Higher Education (London, 24 March 2020) <www.timeshighereducation.com/blog/during-crisis-publishers-mustallow-greater-access-their-content>; C McCluskey-Dean, 'Lobbying for fairer ebook access' (Information in the Curriculum, 12 May 2020) <https://blog.yorksj.ac.uk/infoincurriculum/2020/05/12/lobbying-for-fairerebook-access $/>$. For pre-pandemic analysis of the pricing of e-books and digital content, see eg R Morais, J Bauer and L Borrell-Damián, EUA Big Deals Survey Report: The First Mapping of Major Scientific Publishing Contracts in Europe (European University Association April 2018)

$<$ https://eua.eu/resources/publications/321:eua-big-deals-survey-report-the-first-mapping-of-majorscientific-publishing-contracts-in-europe.html>; J Secker, E Gadd and C Morrison, Understanding the Value of the CLA Licence to UK Higher Education (Universities UK (UUK)/GuildHE CNAC July 2019)

$<$ https://ukcopyrightliteracy.files.wordpress.com/2019/07/cnac-research-project-report-final-with-logos1.pdf $>$.

9 See CLA UUK/GuildHE Higher Education Licence (2019-2022), full terms and conditions <https://cla.co.uk/sites/default/files/CLA-HE-Licence.pdf>. The CLA Licence covers copying from hard copy and digital sources and contains quantitative limits (typically 10 per cent or an article or chapter): clause 3.4. As discussed in Section 2.1, there have been temporary changes to the CLA Licence in response to COVID.

10 For discussion of the use of films and audiovisual works in online teaching, see E Hudson, 'Copyright guidance for using films in online teaching during the COVID-19 pandemic' (4 August 2020)

$<$ https://ssrn.com/abstract=3667025>. The Educational Recording Agency (ERA) offers licences to schools and universities to use, for educational purposes, television and radio programmes of its members. However, this licence applies only to broadcasts and not audio-visual content more generally. Full terms and conditions at <https://era.org.uk/app/uploads/2020/04/ERA-Licence-Schedule-2020.pdf>.

11 Eg letter from D Prosser (Executive Director of Research Libraries UK) and other signatories to G Williamson (Secretary of State for Education) and O Dowden (Secretary of State for Digital, Culture, Media and Sport) dated 30 March 2020 (RLUK letter), requesting a 'statement from government' that section 171(3) 'can be used as a defence by public libraries, research organisations and educational establishments for as long as the current crisis lasts'. 
including that it would require a radical reconceptualisation of this (already controversial) defence. In contrast, there are more promising indications that public interest arguments might be relevant to remedies, notably injunctions. In Section 4, we consider licensingbased solutions. We start with compulsory licensing, which the UK government ruled out on the basis that it is likely to be incompatible with the international copyright framework'. ${ }^{12}$ While we doubt this proposition as a matter of law, we accept that there are reasons why compulsory licensing is not a viable way forward at this time. That said, it is important that industry stakeholders reach negotiated solutions, and we suggest amendment of section 36 of the Copyright, Designs and Patents Act 1988 (CDPA) as one way to encourage this.

There are many issues that, for reasons of space and focus, we are unable to cover, including whether some publishers may be abusing a dominant position for the purposes of competition law. ${ }^{13}$ That said, we include in Section 5 some brief remarks about whether COVID may provide further support for calls for the university sector to embrace open access not just for research but for teaching outputs such as textbooks.

\section{The prevailing copyright environment}

As noted in Section 1, different countries have adopted different mechanisms to facilitate the use of copyright works in education. In the UK, the clear policy choice has been to encourage the roll-out of voluntary blanket licences and to enact exceptions which permit certain uses without remuneration. ${ }^{14}$ We deal with licensing and exceptions in turn.

\subsection{LICENSING}

Educational institutions have a number of different licensing options beyond one-on-one or transactional negotiation, including joining the blanket licences offered by collectives such as CLA and ERA, and executing licences with the producers of subscription databases and other digital products. One might also refer, here, to using resources distributed under Creative Commons licences. ${ }^{15}$ Although reliant on the copyright system for their operation, Creative Commons licences remove many of the usual impediments to licensing by being applied prospectively by the creator rather than negotiated with the user. They are also unremunerated, reflecting the sharing and remix philosophy that sits behind the Creative Commons movement.

During the pandemic, copyright owners and collectives have implemented a number of initiatives to support education. For instance, some publishers have increased access to online textbook platforms. ${ }^{16}$ In mid-April, the CLA Licence was temporarily revised to increase the quantitative copying limits for printed books, meaning that universities were able to copy up to 30 per cent or three chapters, although not where a digital edition

12 Letter from A Solloway (Parliamentary Under-secretary of State - Minister for Science, Research and Innovation) to D Prosser dated 23 April 2020 (Solloway letter). The RLUK letter and the Solloway letter are each reproduced in full at <www.rluk.ac.uk/letter-to-ministers-copyright-and-enabling-remote-learning-andresearch-during-the-covid-19-crisis/ $>$.

13 For a summary of how the relevant legal principles might apply to the exploitation of intellectual property rights, see L Bently, B Sherman, D Gangjee and P Johnson, Intellectual Property Law (5th edn, Oxford University Press 2018) 334-344.

14 Summarised in ibid 262-263.

15 See < https://creativecommons.org>; and see summary in Bently et al (n 14) 309-312.

16 See items linked to in C Morrison and J Secker, 'Copyright, fair dealing and online teaching at a time of crisis' (UK Copyright Literacy, 18 March 2020) < https:/ / copyrightliteracy.org/2020/03/18/copyright-fairdealing-and-online-teaching-at-a-time-of-crisis $/>$. 
is 'available through commercial channels'. ${ }^{17}$ These revised terms expired on 30 June 2020. At the time of writing, university representatives have been lobbying for the extended terms to be reinstated, ${ }^{18}$ and for educational establishments to be able to secure affordable access to electronic content. ${ }^{19}$ This reflects the concern that publisher responses to COVID were one-off, time-limited accommodations to help universities at a time when urgent steps were required, given the imposition of lockdown measures by the UK government. But for many universities, the disruption to teaching in the 20/21 academic year will be even more significant. It is one thing to move a relatively small amount of teaching online and to cancel in-person exams. It is another to teach students remotely for an entire academic year, including to those outside the UK, and possibly against the backdrop of a dramatic fall in university income.

\subsection{EXCEPTIONS}

Exceptions and limitations directed specifically to education are contained in sections 32 to 36A of the CDPA. Other exceptions are also relevant, such as: fair dealing for the purpose of quotation, research or private study, criticism or review, and caricature, parody or pastiche; ${ }^{20}$ the libraries and archives provisions; ${ }^{21}$ and exceptions for users with a disability. ${ }^{22}$ We elaborate on some of these exceptions, below, but wish to preface this analysis by emphasising that there is much (often untapped) flexibility in these provisions. $^{23}$ While we are interested in assessing the merits of new interventions to respond to COVID, this is not to understate the power of existing provisions; and indeed we would urge the sector, especially when making representations to government and other stakeholders, not to concede too much by focusing on the limits and perceived uncertainty of current exceptions. ${ }^{24}$

As noted above, a number of fair dealing exceptions are relevant to education, but for the purposes of this article we focus on fair dealing for the purpose of illustration for instruction (section 32), which was introduced into the CDPA in 2014. This exception applies to all types of copyright work. ${ }^{25}$ It can be used by those giving or receiving

17 See <https://cla.co.uk/sites/default/files/HE\%20Licence\%20Amendment\%20Addendum.pdf $>$.

18 See letter from D Anderson-Evans (Chair, Copyright Negotiating and Advisory Committee, UUK) to J Bennett (Head of Rights and Licensing, CLA) dated 24 June $2020<$ www.rluk.ac.uk/rluk-supports-theuuk-cnac-call-for-the-extension-the-he-licence-terms>; M Reisz, 'Universities offered reprieve in pandemic book licensing battle' Times Higher Education (London, 11 July 2020)

$<$ www.timeshighereducation.com/news/universities-offered-reprieve-pandemic-book-licensing-battle >. On 20 August 2020, CLA announced that there would be a further change to the terms of the CLA Licence in response to COVID-19. This change means that institutions may copy up to two chapters or 20 per cent of print books of participating publishers. These revised terms are effective to 31 July 2021. For full details, see <https://cla.co.uk/HE-licence-terms-amended-covid19>.

19 See also 'Jisc and Universities UK call for publishers to reduce their fees to maintain access to essential teaching and learning materials' (Jisc News, 17 June 2020) <www.jisc.ac.uk/news/jisc-and-universities-uk-callfor-publishers-to-reduce-their-fees-to-maintain-access-to-essential-teaching-and-learning-materials-17-jun$2020>$.

20 CDPA, sections 30(1ZA), 29(1), 29(1C), 30(1) and 30A, respectively.

21 Especially CDPA, sections 41 (interlibrary supply) and 42A (copying requests for published works).

22 Especially CDPA, sections 31B and 31BA (accessible copies made by authorised bodies).

23 See generally E Hudson, Drafting Copyright Exceptions: From the Law in Books to the Law in Action (Cambridge University Press 2020). For analysis of section 32 and interpretations in the higher education sector, see C Morrison, Illustration for Instruction and the UK Higher Education Sector: Perceptions of Risk and Sources of Authority (MA Thesis, King's College London, 2018) < https://kar.kent.ac.uk/73310/>.

24 To illustrate, in the RLUK letter ( $\mathrm{n}$ 11), concern was expressed that 'fair', in relation to education, is 'usually interpreted as, for example, a few lines of a poem, or a single book chapter'. 
instruction or preparing for same ${ }^{26}$ and is not limited to instruction taking place in educational institutions. The CDPA does not define 'illustration for instruction', and we see no reason to interpret this language narrowly. For instance, Recital 21 to the DSM Directive, discussing the new exception for the digital use of works for illustration for teaching, states that this provision 'should be understood as covering digital uses of works or other subject matter to support, enrich or complement the teaching, including learning activities' ${ }^{27}$ This can be contrasted with guidance issued in 2014 by the UK Intellectual Property Office which said that, to rely on section 32, 'the work must be used solely to illustrate a point', 28 and that the exception permitted 'minor uses'. ${ }^{29}$ We believe these statements are unduly conservative and would frustrate the legislative goal of enhancing the use of digital technologies in education. ${ }^{30}$ In this regard, we were pleased to read statements from the UK government in April 2020 that support a meaningful role for section 32 in online education, including that ' $[\mathrm{m}]$ any materials used in presentations by teachers, including those which are streamed remotely to students, are likely to fall within [section 32]' and that '[i]t is likely that the courts will take a generous view of fair dealing during the present crisis, in particular where licences for the reasonable use of works are unavailable? 31

Applying this to teaching activities, we believe that section 32 can cover the inclusion of literary quotations, photographs and images on slides and in other learning materials distributed digitally to students, and the playing of musical and audio-visual works as part of online instruction. We believe that this can extend to entire works in some circumstances. ${ }^{32}$ To give a straightforward example, consider teaching the case Norowzian $v$ Arks to students studying intellectual property law. ${ }^{33}$ In that case, Mr Norowzian alleged that copyright in his short film, Joy (approximately one minute in length), was infringed by a television advertisement for Guinness beer. We believe that playing both films in full is fair, so that students can properly understand the legal issues in the case and form their own view on the conclusion that there was no reproduction of a substantial part. Note that when giving this lecture in person the situation is more straightforward as section 34

26 Ibid section 32(1)(b).

27 And note Recital 22, stating, inter alia, that the exception or limitation should cover uses of works in the classroom and other venues via digital means, 'as well as uses made at a distance through secure electronic environments, such as in the context of online courses or access to teaching material complementing a given course'. The UK government has indicated that it does not intend to implement the DSM Directive: answer to Copyright: EU Action: Written Question - 4371 by Chris Skidmore dated 21 January 2020. However, it may be that the UK ends up implementing all or part of the DSM Directive (for instance, by reference to a future trade deal with the EU); plus these sorts of indication may provide evidence of the prevailing culture and acquis that remains relevant to interpreting UK provisions.

28 Intellectual Property Office, Exceptions to Copyright: Education and Teaching (Intellectual Property Office October 2014) 3.

29 Ibid 4.

30 Discussed in Hudson (n 23) 285.

31 Solloway letter (n 12).

32 It could be put against us that Recital 21 of the DSM Directive, which we cited earlier, states that '[i]n most cases, the concept of illustration would, therefore, imply the use only of parts or extracts of works'. But the Recital goes on immediately to say, 'which should not substitute for the purchase of materials primarily intended for the educational market'. This suggests the main issue is not quantity per se but market effect. Such a concept is not easy (as discussed in Hudson (n 1)), but we believe that for many copyright works used in teaching there is no economic interest that will be harmed by allowing that work to be viewed or watched by students, even in full - and especially where measures are taken to limit availability and re-use (eg by using lower-resolution images on slides, or by hosting content on password-protected VLEs to which only enrolled students have access).

33 Norowzian v Arks Limited (No 1) [1998] FSR 394; Norowzian v Arks Limited (No 2) [2000] FSR 363. 
would also apply. The effect of that provision is that the performance of a dramatic work and the showing of a film to students at an educational establishment, for the purposes of instruction, are not public performances for the purposes of infringement. But playing a film in an online class or making it available to students via the virtual learning environment (VLE) may implicate other rights, including reproduction and, arguably, communication to the public. ${ }^{34}$ For section 34 to apply, we would need to construe its language to also cover these other rights. While Kitchin J was minded to do something similar in Football Association Premier League v QC Leisure in relation to section 72, that approach was permitted because of the wording and legislative backdrop of that exception. ${ }^{35}$ Furthermore, Kitchin J referred to section 34 in the course of his reasoning, stating that in so far as [the communication right] also confers rights in respect of some of the activities falling within [the public performance right] ... s. 34(2) cannot provide a defence. ${ }^{36}$ That is, Kitchin J saw section 34 as tied solely to public performance in a way

34 A claimant alleging infringement of the communication right in CDPA, section 20, would need to show that there was a communication, for instance through a file being made available or through content being transmitted to students. But even if this could be established, the university might seek to resist the proposition that any such communication was 'to the public', especially where the relevant film or extract was available only to students registered for that module via a password-protected VLE. For the communication right, the CJEU has stated repeatedly that the public 'refers to an indeterminate number of potential viewers and implies, moreover, a fairly large number of people’: eg GS Media BV v Sanoma Media Netherlands BV (C-160/15) [2017] 1 CMLR 30 (Second Chamber), [36]. This emphasis on audience size can be contrasted, to a degree, with the approach to the public performance right in section 19, where factors such as the character of the audience have been significant: eg Duck v Bates (1884) 13 QBD 843. That said, in assessing whether a communication was to the public, courts have considered the cumulative effect of individual acts: eg SGAE $v$ Rafael Hoteles SL (C-306/05) [2006] ECR I-11519 (Third Chamber), [38]; Stichting Brein v Ziggo BV (C-610/15) [2017] ECDR 19, [41]. Whether a university has infringed the communication right would therefore depend, inter alia, on whether the court assessed 'the public' by aggregating acts in different modules, over time and for different films. We should also emphasise that, even if a university succeeded on the section 20 point, it may still need to invoke an exception like section 32 in relation to the argument that it had infringed or authorised the infringement of the reproduction right.

35 FAPL v QC Leisure [2012] EWHC 108 (Ch), esp. [71]-[78]. That case related to the use by UK publicans of foreign decoder boxes to access the broadcast signal for football matches run by FAPL. On referral to the CJEU, it was held, inter alia, that the act of turning on the television in the pub, so that patrons could watch the football, was a communication to the public: FAPL v QC Leisure (Joined Cases C-403/08 and C-429/08) [2012] ECDR 8 (Grand Chamber). On return to the High Court, Kitchin J accepted that there was overlap between the (unharmonised) public performance right in section 19 and the (harmonised) communication to the public right in section 20 . However, he also held that the publicans could have a defence under section 72. That provision stated that 'the showing ... in public of a broadcast to an audience who have not paid for admission to the place where the broadcast is to be seen or heard does not infringe copyright' in the broadcast and any film included in it. (This reference to films was subsequently removed by the Copyright (Free Public Showing or Playing) (Amendment) Regulations 2016 (SI 2016/565).) Kitchin J was able to reach this conclusion because the words of section 72 were unambiguous: the showing or playing of the broadcast does not infringe any copyright in the broadcast or any film included in it, and therefore applied to the rights in sections 19 and 20.

36 FAPL v QC Leisure [2012] EWHC 108 (Ch), [58]. 
that section 72 was not. However, as we have said, educators can instead turn to fair dealing in section 32 in relation to the use audio-visual content in online classes. ${ }^{37}$

The provision of digitised copies of readings might also fall within section 32 , although the arguments are not quite as straightforward. For UK institutions, the need to explore fair dealing has been mitigated by the blanket licence offered by CLA. ${ }^{38}$ In its usual form, that licence allows the copying of a chapter or article or up to 10 per cent of a published work. These limits have been temporarily lifted for the 20/21 academic year so that up to two chapters or 20 per cent of a print book may be copied. ${ }^{39}$ But can UK universities digitise beyond the CLA limits by reference to fair dealing? We can envisage scenarios where the arguments for fair dealing are compelling, for instance where students need to read three chapters from a specialist title that is out of print. Here, one question is whether the required content can be selected by a lecturer but digitised by someone in the library. This is an issue because section 32 applies to dealings by a person giving or receiving instruction', 40 which could be interpreted to mean that a lecturer may not ask a librarian or teaching assistant to undertake the copying. We believe that section 32 ought not to be read in this way. First, it would suggest that the 'person' giving instruction cannot be a university or other establishment. ${ }^{41}$ But for section 32 to function, it is necessary that it can be invoked by legal entities and not just individual members of staff. Second, section 32 does not contain the limits, found in section 29 (fair dealing for non-commercial research or private study), on copying by others. ${ }^{42}$ Our interpretation also accords with university workflows and resourcing, for instance that librarians may have access to better copying equipment and be better placed to produce good quality scans.

But the big question is whether copying under section 32, as supplemented by the libraries and archives provisions, will get universities where they need to be in relation to

37 Although we give the example of including two short films in a copyright lecture, we believe that section 32 could even extend to playing feature films, as explained in detail in Hudson (n 10). Consider the teaching activities in Film Studies. In normal times, such departments routinely screen films in person, under section 34, often using DVDs owned by the university. With the shift to online teaching, we believe that universities can allow students to watch entire feature films by reference to section 32. In developing a fair dealing policy for such practices, universities may benefit from ensuring that their activities mirror, as far as possible, the circumstances in which they screen films in person. This might include only granting access to students in that module, and via a password-protected platform such as the VLE; only allowing access for a limited period; not allowing students to download films; monitoring student usage; not using section 32 for filmmakers or studios with (known) strong preferences regarding rights; and including a copyright warning in addition to the sufficient acknowledgment required by section 32 .

38 Compare equivalent institutions in the USA, where it is common for fair use to be relied upon (along with other strategies) for material included in electronic reserves and posted to VLEs: see Hudson (n 23) 194 205. This application of fair use to such practices was challenged in the Georgia State litigation. For the most recent judgment in this litigation, see Cambridge University Press v Becker (ND Georgia, 2 March 2020); and for a summary of the litigation, see Hudson (n 1).

39 See $n 18$ and surrounding text.

40 CDPA, section 32(1)(b).

41 This would also reflect the usual approach in the case law, in which judges often do not differentiate between the person sued (often a legal entity) and the person who performed the act of copying: see $\mathrm{J}$ McCutcheon and S Holloway, 'Whose fair dealing? Third-party reliance on the fair dealing exception for parody or satire' (2016) 27 Australian Intellectual Property Journal 54; Hudson (n 23) 288-289.

42 CDPA, section 29(3). Paragraph (a) relates to librarians and states that they may not do anything which is not permitted by CDPA, section 42A (request-based copying for published works), while paragraph (b) applies to all other third-party copyists and prevents them from participating in systematic copying. As noted by Bently et al, section 29(3) means that 'lecturers are unable to use the research or private study defence where they make multiple copies of a work for their students': Bently et al (n 13) 243. The existence of paragraph (3) suggests that agency arguments are otherwise available. 
required readings. ${ }^{43}$ For many institutions, the issue is not copying smaller parts, as the CLA Licence provides a workable system for scanning articles, chapters and other extracts, plus VLEs can link to content in subscription databases. Instead, they are concerned about access to entire books where there is no digital version available on the market or that version is prohibitively expensive, subject to unduly restrictive licence terms, bundled with other (unwanted) content, etc.

To us, the most promising argument for unremunerated copying of entire works is a version of controlled digital lending (CDL), which has been implemented in the USA by reference to the first sale doctrine and fair use. ${ }^{44}$ The central idea of this strategy - which we emphasise is highly controversial ${ }^{45}$ - is that libraries can digitise lawfully acquired hard copy titles and then loan digitised as well as physical versions. A strict 'owned to loaned' ratio must be maintained. ${ }^{46}$ If a library owns, say, three copies of a book and it lends a digital version, it must withdraw one of the physical copies while the digital copy is on loan. The conditions of loan should approximate those for a physical title, for instance that each digital copy is loaned to a single user for a period analogous to the loan of a physical work. ${ }^{47}$ Technological interventions are required to limit copying and redistribution by the borrower.

43 As indicated in $\mathrm{n} 42$, there are library exemptions under which students may ask to be supplied with a 'reasonable proportion' of a published work for their own private study: CDPA, section 42A. An important caveat to this provision is that the person making the request must declare that, to the best of that person's knowledge, 'no other person with whom the person ... studies has made, or intends to make, at or about the same time as the person's request, a request for substantially the same material for substantially the same purpose'. Thus, while section $42 \mathrm{~A}$ may be relevant to a student writing a dissertation on a topic of their own devising, it would not apply to compulsory reading set by a lecturer (this contravening the exclusion on systematic copying, given the implicit assumption - which we acknowledge is sometimes wrong - that more than one student will wish to undertake the reading).

44 For an overview CDL and its justification by reference to fair use, see D Hansen and K Courtney, 'A White Paper on controlled digital lending of library books' (Harvard Library Office for Scholarly Communication 2018 ) < http://nrs.harvard.edu/urn-3:HUL.InstRepos:42664235>. The authors trace the idea for CDL back to the 'pioneering article' by Michelle Wu: M Wu, 'Building a collaborative digital collection: a necessary evolution in libraries’ (2011) 103 Law Library Journal 527.

45 One of the best-known practitioners of CDL is the Internet Archive (IA). The IA runs a large-scale digital preservation programme for books, historical documents and internet pages. It also runs an Open Library, in which members of the public may electronically borrow books that have been scanned by the IA. The IA's practices have long been criticised, but these objections intensified in 2020 following roll-out of a National Emergency Library <https://archive.org/details/nationalemergencylibrary>: see eg A Albanese, 'Authors Guild, AAP Outraged by IA's "National Emergency Library"” Publishers Weekly (North Hollywood, 30 March 2020) <https://www.publishersweekly.com/pw/by-topic/digital/copyright/article/82861authors-guild-aap-outraged-by-ia-s-national-emergency-library.html $>$. The key change in the National Emergency Library, compared with the Open Library, was that titles could be borrowed by multiple users simultaneously. On 1 June 2020, a complaint was filed by four major publishers against the IA in relation to its Open Library and National Emergency Library: Hachette Book Group, Inc v Internet Archive (Case 1:20-cv04160, SDNY, 1 June 2020). In this complaint, the plaintiffs described IA's activities as 'willful mass copyright infringement' (paragraph 2) and alleged that IA 'defends its willful mass infringement by asserting an invented theory called "Controlled Digital Lending" ("CDL")—-the rules of which have been concocted from whole cloth and continue to get worse' (paragraph 8). The National Emergency Library closed on 16 June 2020. The Open Library remains in operation. For an overview, see A Romano, 'A lawsuit is threatening the Internet Archive - but it's not as dire as you may have heard' (Vox, 23 June 2020) <www.vox.com/2020/6/23/21293875/internet-archive-website-lawsuit-open-library-wayback-machinecontroversy-copyright $>$.

46 Hansen and Courtney (n 44) 2, quoting from the Position Statement on Controlled Digital Lending by Libraries $<$ https://controlleddigitallending.org/statement $>$.

47 Ibid 3, also quoting from the Position Statement. 
There are a number of issues with CDL. Perhaps the key issue is logistical rather than legal, namely the resources involved in scanning entire books and ensuring that the resulting files have the necessary digital rights management interventions applied. There are also questions about how CDL would apply to reference collections, bearing in mind that some university libraries do not maintain a circulating collection. ${ }^{48}$ If a book may not be borrowed physically can it nevertheless be loaned digitally? In terms of the fair dealing analysis, there are limits in section 32 that are not found in the open-ended fair use exception of US law. The language of 'illustration for instruction' might seem inherently more confined than the illustrative purposes of 'teaching', 'scholarship' and 'research' in the US copyright statute. ${ }^{49}$ One can also imagine fierce disagreement over the use of CDL for titles that are available commercially in digital form. One complaint seen repeatedly from universities is that prices for e-books are often many multiples of the hard copy version, even for single-user licences. But publishers would no doubt argue that there are good reasons for the price differential, and that CDL would involve such an obvious case of market substitution that no fair dealing analysis is tenable. ${ }^{50}$

It may be that, absent government intervention (discussed further in Section 4), a large-scale CDL scheme is unlikely to be rolled out in the UK any time soon. Nevertheless, the US experience with CDL may provide some useful ideas for UK institutions, for instance regarding the matters that might support CDL being a fair dealing, 51 and the sort of limits that might be placed on the accessibility and re-use of digital copies to buttress those arguments. We also observe that the legality of CDL in the UK may be bolstered by section 36A of the CDPA which states, without qualification, that 'copyright in a work is not infringed by the lending of copies of the work by an educational establishment'. This could be a very important supplement to fair dealing. 52 For section 36A to be relevant to CDL, 'lending' must not be limited to physical copies. This proposition is supported by the definition of 'lent out' in the Public Lending Right

48 Eg the collection of the Bodleian Library at the University of Oxford.

49 Copyright Act of 1976 (US), section 107.

50 As seen in the complaint against IA ( $\mathrm{n}$ 45), especially paragraphs 52 (the IA business model is 'parasitic and illegal'), 65 ('IA directly harms the Plaintiffs' print and ebook markets in all market segments by providing competing substitutes for numerous original works currently available in their catalog'), and 119-127 (setting out various types of market harm said to be caused by IA's practices).

51 See Hansen and Courtney (n 44) 16-32 (arguments that support fair use for CDL include: lack of profit by the defendant library or university; CDL facilitates research and learning; the defendant must have already purchased the content being digitised; for out-of-print books, there is no current market for the work; although entire works can be digitised (which can tend against fair use), this is offset by limits on loan duration, DRM to prevent re-use, etc; any market effect of CDL mirrors that of lending physical works, which is permitted by the first sale doctrine; and in many instances, there is no functioning digital market).

52 Just as the first sale doctrine is important for CDL in the USA: see ibid 11-16, where the authors argue that that CDL 'closely mimics the economic transaction that Congress has already provided for through the first sale doctrine under Section 109' (11), and that this favours fair use. We also note that, in future, CDPA, section 40B, could have work to do. That provision allows libraries and educational establishments, amongst others, to 'make available to the public by means of a dedicated terminal on its premises' a work or copy of a work that 'has been lawfully acquired by the institution'. If 'on its premises' is read literally (as the CJEU seemed to do in Technische Universität Darmstadt v Eugen Ulmer KG (C-117/13) [2014] ECDR 23 (Fourth Chamber)), this will not help with electronic lending to recipients located elsewhere, even if over a secure network which permits viewing but not downloading. But if 'premises' is read more broadly - or if section $40 \mathrm{~B}$ were amended in a post-Brexit world - then that provision could also be useful for facilitating online access to staff and students. 
Act 1979, which includes digital lending: 53 and section 40A of the CDPA, in relation to lending by public libraries, which likewise applies to the lending of e-books. ${ }^{54}$ Such a definition was also accepted by the Court of Justice of the EU (CJEU) in Vereniging Openbare Bibliotheken v Stichting Leenrecht. 55 The VOB, the Netherlands Association of Public Libraries, sought a declaration that digital lending of e-books fell within an existing remunerated exception in the Dutch Copyright Act. ${ }^{56}$ The case was referred to the CJEU in relation to various questions under the Rental and Lending Rights Directive. ${ }^{57}$ The CJEU stated that, while the right of rental relates only to tangible objects, lending is a separate concept and could extend to digital copies.

It might be argued that section 36A of the CDPA is superfluous insofar as it relates to the lending right in section 18A, as that right only relates to lending 'through an establishment which is accessible to the public'. ${ }^{58}$ The argument that university libraries are not (usually) publicly accessible is supported by the definition of library in section $43 \mathrm{~A}(2)$ of the CDPA, where that term means '(a) a library which is publicly accessible, or (b) a library of an educational establishment'. This would not necessarily render section 36A redundant, as its language suggests that it applies to other restricted rights that might be implicated in the course of lending. ${ }^{59}$ This might conceivably include digitising hard copy titles in order to lend them, ${ }^{60}$ along with any acts of reproduction

53 Public Lending Right Act 1979, section 5(2), as amended by the Digital Economy Act 2017, section 31(1) ("lent out" means made available to a member of the public for use away from library premises for a limited time (including by being communicated by means of electronic transmission to a place other than library premises) and "loan" and "borrowed" are to be read accordingly").

54 CDPA, section $40 \mathrm{~A}(1 \mathrm{~A})(\mathrm{d})$ states that in subsection (1), lending 'is to be read in accordance with the definition of 'lent out' in section 5 of [the Public Lending Right Act 1979]'. Section 40A provides that certain acts carried out by a public library do not infringe copyright when carried out in relation to books within the public lending right scheme. It was revised in 2017 to state that this exclusion only applies to ebooks where 'the book has been lawfully acquired by the library' and 'the lending is in compliance with any purchase or licensing terms to which the book is subject': section $40 \mathrm{~A}(1 \mathrm{ZA})$.

55 Vereniging Openbare Bibliotheken v Stichting Leenrecht (C-174/15) [2017] ECDR 3 (Third Chamber).

56 For a summary of events leading up to the test case brought by Vereniging Openbare Bibliotheken, see V Breemen, 'E-lending according to the ECJ: focus on functions and similar characteristics in VOB $v$ Stichting Leenrecht (2017) 39 European Intellectual Property Review 249.

57 Directive 2006/115/EC of the European Parliament and of the Council of 12 December 2006 on rental right and lending right and on certain rights related to copyright in the field of intellectual property (RLD).

58 CDPA, section 18A; see also RLD, Article 2(1) (definition of lending limited to acts 'made through establishments which are accessible to the public').

59 Section 36A states that 'copyright ... is not being infringed by the lending', without limiting that copyright to any particular rights. For similar arguments, see the discussion of CDPA, section 72, as interpreted by Kitchin $\mathrm{J}$ in FAPL (n 35).

60 For analysis of the same question in relation to the dedicated terminals exception in Article 5(3)(n) of Directive 2001/29/EC of the European Parliament and of the Council of 22 May 2001 on the harmonisation of certain aspects of copyright and related rights in the information society (ISD) (in the UK, CDPA, section 40B), see Technische Universität Darmstadt v Eugen Ulmer KG (n 52), discussed in Hudson (n 23) 152-153. The CJEU accepted that Article 5(3)(n) 'would risk being rendered largely meaningless, or indeed ineffective, if those establishments did not have an ancillary right to digitise the works in question': [43]. The CJEU located this right in Article 5(2)(c), which permits member states to recognise an exception or limitation to the reproduction right in respect of specific acts of reproduction made by publicly accessible libraries, educational establishments or museums, or by archives, which are not for direct or indirect economic or commercial advantage'. Without a directly equivalent provision in the CDPA, it has been suggested that UK institutions could digitise pursuant to the preservation copying exception in section 42 . 
and communication in effecting the digital loan. ${ }^{61}$ Even if we are wrong on this extended reach of section $36 \mathrm{~A}$, institutions could still point to other exceptions to undertake these acts, such as fair dealing in section $32 .{ }^{62}$ Whichever route is taken, it is clear that the library would not be able to digitise or make available a copy from an unlawful source. ${ }^{63}$

We wish to make two final points in relation to fair dealing. First, section 32 contains two further requirements that we have not yet mentioned: that the dealing is for a noncommercial purpose and that it is accompanied by a sufficient acknowledgment (unless this would be impossible). ${ }^{64}$ The non-commercial purpose limitation is addressed to the dealing, meaning that the status of the organisation or establishment relying on section 32 is not determinative. ${ }^{65}$ The need for a sufficient acknowledgment appears in a number of fair dealing provisions and is defined to mean identification of the work and its author. ${ }^{66}$ This is not the same as a full-blown academic citation and can be satisfied by use of names, descriptions, logos etc. ${ }^{67}$ Secondly, although this article has focused on section 32, university staff and students can rely on other fair dealing exceptions. We draw particular attention to fair dealing for the purpose of quotation, which was introduced

61 Applying Nederlands Uitgeversverbond v Tom Kabinet Internet BV (C-263/18) [2020] ECDR 1 (Grand Chamber), it is not obvious to us that CDL would necessarily involve a communication to the public. In that case, Tom Kabinet ran an online reading club. Members of the club could access a virtual market where they could buy 'second-hand' e-books. The CJEU indicated that there was a communication as Tom Kabinet made the digital files available to anyone who was a member of the reading club: [65]. Furthermore, it was 'to the public' as anyone could join the club, and there were no technical measures that limited the accessibility of files. This allowed the conclusion that 'the number of persons who may have access, at the same time or in succession, to the same work via that platform is substantial': [69]. In contrast, under CDL, files are transmitted to or accessed by individual users on a strict owned-to-loaned basis. Similar to the discussion of the screening of films to students (see n 34 above), much will turn on whether a court will nevertheless aggregate individual acts of borrowing to say that communication was to a sufficiently large group of people to constitute the public.

62 Compare G Spedicato, 'Digital lending and public access to knowledge' in J Lai and A Dominicé (eds), Intellectual Property and Access to Im/ material Goods (Edward Elgar 2016) 154. Spedicato observes that digital lending in Europe typically occurs by reference to licensing agreements, as a 'wide consensus has emerged in Europe on the view that digital lending should not come under any of the exceptions or limitations provided for by the EU copyright system'. Spedicato says that digital lending implicates the making available right (which we discuss in $n 61$ above), but that there is no exception or limitation in Article 5 of the ISD that mirrors Article 6 of the RLD (which allows member states to derogate from the public lending right through the creation of public lending rights schemes). Even if this analysis is correct for public libraries, we believe that university libraries running CDL can point to a number of exceptions and limitations to justify digital lending, including ISD Articles 5(2)(c) (for the digitisation aspect) and (3)(a) and DSM Directive Article 5(1). For UK universities, concerns about compliance with Article 5 may recede if and when the UK is no longer bound by EU copyright law.

63 Similar Vereniging Openbare Bibliotheken v Stichting Leenrecht (n 55), where the CJEU held that for a public lending exemption to apply as permitted by Article 6 of the Directive, the digital copy must not have been obtained from an 'unlawful source'. That conclusion was prompted by concerns about the circulation of pirated copies.

64 CDPA, section 32(1)(a), (c).

65 See Bently et al (n 13) 232-233, noting that an in-house education seminar might be non-commercial even if undertaken by a for-profit business and that not-for-profit entities may undertake commercial activities, such as selling academic books.

66 CDPA, section 178.

67 Eg in Pro Sieben Media AG v Carlton UK Television Limited [1999] FSR 610, 624-625, the requirement for a sufficient acknowledgment was satisfied by the appearance of a logo on a television programme. 
into the CDPA 2014. This is a significant expansion to the fair dealing family and can apply to numerous acts by educators and students. ${ }^{68}$

In conclusion, many practices of educators and students fall within existing exceptions, including in an online environment. We have also argued that educators could make further use of exceptions, for instance in the digitisation and supply of reading materials that fall outside of the CLA Licence. But we recognise that the challenges posed by COVID cannot be answered solely by the existing exceptions. Some of our suggestions would be novel for UK universities, for instance that CDL-style reasoning might inform reliance on sections 32 and 36A. We can imagine universities being selective in any digitisation of larger extracts or entire works, for reasons that include both the resource intensiveness of scanning and the need to undertake a legal assessment of each work. In addition, for universities teaching students located overseas, there is the issue that copyright law is territorial. That means that if, say, a UK university makes digitised readings available to students studying in Australia, the question of whether there is infringement in Australia will be judged by reference to Australian law. ${ }^{69}$ Although in many instances there will be similar exceptions elsewhere, ${ }^{70}$ and for many uses a very low risk of any complaint, this represents a limit for exceptions analysis. Taken together, these issues illustrate why licensing solutions may be even more attractive for some uses, for instance if licence arrangements permit universities to access born-digital content or scans made by other institutions, and if the licence extends to students located around the

68 CDPA, section 30(1ZA); for an overview, see Hudson (n 10) (focusing in particular on the use of films and audio-visual works in online teaching); Hudson (n 23) 276-284. In July 2019, the CJEU handed down three judgments that considered quotation: Pelham GmbH v Hütter (C-476/17) [2019] Bus LR 2159 (Grand Chamber); Spiegel Online v Beck (C-516/17) [2019] Bus LR 2787 (Grand Chamber); and Funke Medien NRW GmbH v Germany (C-469/17) (Grand Chamber, 29 July 2019). Following those cases, a number of matters are clear in relation to the quotation exception in EU copyright law: it can apply to any type of copyright work; it can apply to entire works; and it is not necessary for the quotation to be made in a work that is also protected by copyright. The CJEU also clarified that member states enjoy discretion in the operation of certain elements of the quotation exception, namely the purposes for which quotation can be applied, proportionality and fair practice. Although it has been argued that quotation is not limited to any particular purpose (only requiring that the defendant has a purpose), in Pelham $v$ Hütter the CJEU identified the 'essential characteristics' of quotation as use of a work or extract 'for the purposes of illustrating an assertion, of defending an opinion or of allowing an intellectual comparison between that work and the assertions of that user': [71]. Although the CJEU suggested at [72] that music sampling might involve a quotation, the German Federal Court of Justice stated, on the return of the case, that none of quotation, parody or caricature apply to sampling. The court did, however, suggest that sampling might fall within pastiche: A Hui, '21 and illegal in all states? The German Pelham court confirms when sampling is illegal' (The IPKat, 5 May 2020) http://ipkitten.blogspot.com/2020/05/guest-post-21-and-illegal-in-all-states.html. For analysis of the pastiche exception, including the argument that it applies to sampling (amongst numerous other uses such as mash-ups and fan fiction), see E Hudson, 'The pastiche exception in copyright law: a case of mashed-up drafting?' [2017] Intellectual Property Quarterly 346. For analysis of quotation, see T Aplin and L Bently, Global Mandatory Fair Use: The Nature and Scope of the Right to Quote Copyright Works (Cambridge University Press forthcoming 2020).

69 Liability will turn on the scope of rights and exceptions in the country in which the student is located. In the mandatory exception for education in the DSM Directive this is dealt with through a deeming provision that the use of works through secure electronic environments shall be taken to occur 'solely in the Member State where the educational establishment is established': DSM Directive, Article 5(3).

70 In Australia, there is no fair dealing exception for education, but there is fair dealing for research and study and an exception in section 200AB of the Copyright Act 1968 (Cth) for certain uses by cultural and educational institutions: for discussion of the latter, see Hudson (n 23) chapter 6. On 13 August 2020, the Australian government announced that it will make a series of reforms to the Copyright Act, including introducing a new fair dealing exception for non-commercial quotation and amending the existing education exceptions: Australian Government, Copyright access reforms (13 August 2020) $<$ https://www.communications.gov.au/departmental-news/copyright-access-reforms >. 
world. We return to licensing in Section 4. Before then, we consider in Section 3 another set of arguments in relation to copyright and COVID: whether educational establishments might be able to argue the public interest as a defence to copyright infringement or in the assessment of remedies. Might these arguments limit the need for licensing solutions?

\section{The public interest}

\subsection{AS A DEFENCE}

As noted in the introduction, in its letter to the government, Research Libraries UK asked for confirmation that section 171(3) 'can be used as a defence by ... educational establishments for as long as the current crisis lasts'. ${ }^{71}$ Section 171(3) states that '[n]othing in this Part affects any rule of law preventing or restricting the enforcement of copyright, on grounds of public interest or otherwise'. An initial question is whether this provision permits the recognition of a public interest defence in addition to the exceptions and limitations set out in the statute. Although the Court of Appeal answered this question in the negative in Hyde Park Residence $v$ Yelland, ${ }^{72}$ it changed approach in Ashdown v Telegraph Group Limited. ${ }^{73}$ The court reasoned that the entry into force of the Human Rights Act 1998 meant that there may be cases - albeit rare - where a public interest defence was needed to protect the freedom of expression of the defendant. It is open to question whether this defence remains available following the CJEU judgments in Spiegel Online and Funke Medien. ${ }^{74}$ In those cases, it was held that the harmonisation of exceptions and limitations under Article 5 of the ISD is exhaustive, and that member states may not recognise any further derogation from the author's exclusive rights by reference to provisions of the Charter of Fundamental Rights of the European Union. As such, the suggestion that UK universities might, during the pandemic, invoke a public interest defence to copyright infringement could be met with the knockdown argument that the defence no longer exists.

We could stop there, but we believe it is nevertheless useful to explore the public interest defence, especially given the possibility that, at the end of this year, the UK will no longer be bound by EU copyright law. As Jonathan Griffiths has said, 'we know remarkably little' about the public interest defence in copyright, ${ }^{75}$ and so an important debate remains to be had about its scope. Perhaps the only thing that is clear, as Griffiths also notes, is that judges have shown little appetite to deny copyright claims on public interest grounds. In contrast, in other contexts, such as breach of confidence, misuse of private information and defamation, public interest jurisprudence is fairly mature. Given overlaps in the fact patterns that give rise to claims in copyright, breach of confidence and misuse of private information, a proper understanding of this latter group of claims is useful to determining its parameters in copyright.

71 RLUK letter (n 11).

72 [2001] Ch 143 (Aldous LJ with whom Stuart-Smith LJ agreed, Mance LJ dissenting). Although Aldous LJ rejected the proposition that there existed, in copyright, a public interest defence equivalent to that in the law of confidence, he accepted that there are limited circumstances where a court may refuse to enforce the copyright in a work because this would offend against the policy of the law. We return to this at $\mathrm{n} 81$ below and surrounding text.

73 [2002] Ch 149.

74 Discussed above n 68, in relation to quotation.

75 J Griffiths, 'Pre-empting conflict - a re-examination of the public interest defence in United Kingdom (UK) copyright law' (2014) 34 Legal Studies 76, 77. 
Public interest defences are commonplace in civil law claims. They safeguard meritorious interferences with personal and/or property rights. As is commonly noted, the term 'public interest' lacks precise or fixed definition, although its core meaning can be sketched easily enough, as a wide range of commentators (one of us included) have observed. ${ }^{76}$ Whereas some commentators have criticised this imprecision, an alternative response is that this fuzzy penumbra provides judges with the discretion to ensure justice is served when novel fact patterns emerge.

Importantly, what unites these exceptional interferences with rights is that there is an underlying public interest in the information itself which justifies that interference. For example, in Lion Laboratories $v$ Evans, ${ }^{77}$ it was in the public interest to know that the claimant's breathalyser equipment, which was used by the police, may be inaccurate and so lead to unfair prosecutions. The misuse of private information jurisprudence has seen this exception swell to encompass the right to criticise morally wrong behaviour, as where a newspaper exposed the adultery of a former England football team manager. ${ }^{78}$ We can therefore interpret the public interest defence as a sort of public policy exception that denies rights claims where the rights of others have been unduly harmed. Of course, as with all discretionary powers, it is susceptible to misuse (intentional or otherwise), for it can allow judges to take their own moral view and call it 'the public interest'. ${ }^{79}$

It is understandable, in the current climate, that educators might argue that COVID presents such novel circumstances that it is in the public interest to limit or suspend rights in copyright content. It is also understandable why they would be attracted to that idea, since it is well established that the presence of a public interest tends to operate as a 'determinative factor' 80 in deciding claims. But although it may appear intuitive this application of the public interest defence strikes us as unsustainable and deeply implausible, as it would contravene the operative normative reasoning inherent in the defence.

Whereas the definition of the term is flexible, its function is fixed. It is the lens by which the courts scrutinise qualities in the contested material itself - be that copyrighted, defamatory, private or confidential information - and not the wider context of the litigation. In this way, the 'public interest' acts as a sort of tiebreaker where two rights claims are otherwise ostensibly equivalent. Across the range of common law and equitable causes of action - from claims in breach of confidence and misuse of private information to defamation, copyright and even data protection - the question of a public interest defence only arises if the defendant can establish a prima facie right to counteract the original rights claim. Consequently, it may be said that the public interest defence is parasitic upon an underlying rights-claim capable of providing some prima facie justification for the breach.

76 See eg E Barendt, Freedom of Speech (2nd edn, Oxford University Press 2005); H Fenwick and G Phillipson, Media Freedom under the Human Rights Act (Oxford University Press 2006); T Aplin, 'The development of the action for breach of confidence in a post-HRA era' [2007] Intellectual Property Quarterly 19; P Wragg, 'A freedom to criticise? Evaluating the public interest in celebrity gossip after Mosley and Terry' (2010) 2 Journal of Media Law 295; Griffiths (n 75).

77 [1985] QB 526.

78 McClaren v Mirror Group Newspapers Limited [2012] EWHC 2466; see also Ferdinand v Mirror Group Newspapers Limited [2011] EWHC 2454; Terry v Persons Unknown [2010] EWHC 119; and Hutchinson v News Group Newspapers Limited [2011] EWCA Civ 808.

79 For example, see criticisms of cases in P Wragg, 'The benefits of privacy-invading expression' (2013) 64 Northern Ireland Legal Quarterly 187.

80 Kv News Group Newspapers Limited [2011] EWCA Civ 439, [23]. 
Most obviously, but not always, this countervailing right is freedom of expression under Article 10 of the European Convention on Human Rights. Alternatively, it may arise as the State's right to override personal or property rights so as to safeguard the public interest against breaches of national security or civil unrest or to protect (as in the case of COVID itself) the health and safety of citizens or their moral well-being. The State's interest, though, typically manifests in a negative form to deny the rights-claim. Indeed, we see this state interest in the limited public interest exclusion outlined by the Court of Appeal in Hyde Park Residences Limited v Yelland:

[A] court would be entitled to refuse to enforce copyright if the work is: (i) immoral, scandalous or contrary to family life; (ii) injurious to public life, public health and safety or the administration of justice; (iii) incites or encourages others to act in a way referred to in (ii). ${ }^{81}$

In our paradigm, the university's claim does not fit the language of rights, whether relating to property, the person or the State. Although its conduct may support a noble, publicserving goal - such as access to education or information - its claim is too general and not rights-based. Universities are not saying, for example, that infringement of copyright amounts to or is in pursuance of a free speech claim, as it was in, say, Ashdown $v$ Telegraph Group. ${ }^{82}$ Nor are they saying that there is something about the copyright material specifically that warrants either dissemination to a wider group or suppression of that information. The claim is not that there is something within the materials that the public ought to know; nor is there is any moral or legal wrong disclosed in that material that universities wish to criticise. In fact, the material itself is largely irrelevant. Instead, the public interest claim relates to the costs of obtaining and licensing that content. Thus, the institution's response to copyright infringement is, and can be no more than, a plea of poverty. They cannot afford the price of compliance.

Properly speaking, this is not a public interest defence at all. It is more like a necessity defence which resides not in the material itself but in the social, political and economic environment in which the university is operating. The institution is claiming that in order to provide a quality educational service it had to infringe copyright. It might even point to the actions of copyright owners, for instance in relation to pricing, as compounding this need. ${ }^{83}$ We agree with the concern that there are copyright-related impediments to teaching during COVID and appreciate that many universities are facing very worrying economic forecasts. But acceptance that this enlivens a public interest defence would give that defence an entirely new function, and one that could be difficult to contain. Although the current pandemic may be seen as exceptional, it is not sui generis. If judges were to tolerate the suspension of rights in this context, why not others where there is major economic and social upheaval? Thus, to the extent there still exists in UK copyright law a public interest defence, there are many problems in applying it as a general safety valve during the pandemic.

\subsection{IN THE ASSESSMENT OF REMEDIES}

While the socio-economic climate cannot sustain a public interest defence to copyright infringement, there are more promising arguments that such circumstances may have a bearing on the assessment of remedies. In a claim for infringement, the copyright owner

81 Hyde Park Residences Limited v Yelland (n 72) [66] (emphasis added).

82 Ashdown v Telegraph Group (n 73). Even in that case, the public interest defence was unsuccessful.

83 As noted earlier, we have not discussed the competition law concern about abuse of dominant position. 
will most likely seek a final injunction and damages for lost sales or licence fees. We deal with injunction and damages in turn.

Although the injunction is a discretionary equitable remedy and judges may therefore refuse an injunction and instead award damages in lieu, 84 in intellectual property law, a culture has arisen in which injunctions are generally granted as if of right. As illustrated most graphically by Chiron v Organon Teknika, this has been the case even where there is a strong public interest in having continued access to the defendant's infringing product. ${ }^{85}$ There are a number of justifications for this approach, including that each intellectual property regime has already been crafted to reflect public interest concerns; that refusing to order an injunction has the practical effect of sanctioning the defendant's wrongful conduct; and that there are significant difficulties in judges calculating damages in lieu (especially where the infringing conduct may occur for many years into the future).

There are also signs, however, that UK courts are becoming more receptive to public interest arguments. Although such arguments have been accepted from time to time, ${ }^{86}$ this has been very controversial. ${ }^{87}$ It is therefore significant that in Coventry $v$ Lawrence, the Supreme Court, in discussing the jurisdiction to award damages in lieu, emphasised the discretionary nature of the injunction and the need to consider all the relevant facts, including the public interest. ${ }^{8}$ In addition, it has been suggested that for intellectual property cases, the availability of an injunction must be considered in light of the Enforcement Directive, which in Article 3 says that remedies must be fair, equitable, effective, proportionate and dissuasive, amongst other things. ${ }^{89}$ Both Coventry and Article 3 were considered by Birss $\mathrm{J}$ in Evalve Inc $v$ Edwards Lifesciences Limited, handed down in March $2020 .{ }^{90}$ In that case it was held that the defendant's device, used to treat mitral valve regurgitation, infringed patents held by the claimants. ${ }^{91}$ The defendant sought to resist an injunction on the basis that, in essence, many doctors preferred the defendant's product to that of the claimants. Birss J observed that the 'previous reluctance' to refuse an injunction stemmed from Shelfer's Case, but that the Supreme Court had concluded, in Coventry, that 'a more flexible approach should be taken'.92 That said, he also held that, when applying Coventry to patent infringement, it remained necessary to consider how the patent system already embodies the public interest, just as Aldous J had done in Chiron v

84 Now found in Senior Courts Act 1981, section 50.

85 Chiron Corporation v Organon Teknika Limited (No 10) [1995] FSR 325. That case concerned the infringement of patents in relation to diagnostic tests for hepatitis. The defendants argued that the judge should award damages in lieu of an injunction, but these arguments were rejected. Although accepting that Shelfer $v$ City of London Electric Lighting Co [1895] 1 Ch 287 did not describe exhaustively the circumstances in which such discretion could be exercised, and that the interests of the public might be relevant, Aldous J emphasised the various ways in which the patent monopoly is limited. Given these limitations, he concluded at 334 that it is a good working rule that an injunction will be granted to prevent continued infringement of a patent, even though that would have the effect of enforcing a monopoly, thereby restricting competition and maintaining prices. Something more should be established before the Court will depart from the good working rule suggested in the Shelfer case.'

86 Especially the (in)famous Miller v Jackson [1977] 1 QB 966, in which an injunction was declined on the basis that there was a public interest in playing cricket.

87 See eg J Heydon, M Leeming and P Turner, Meagher, Gummow \& Lehane's Equity: Doctrines and Remedies (5th edn, LexisNexis Butterworths 2015) [21-095] (describing Miller v Jackson as a 'judicial aberration').

88 Coventry $v$ Lawrence [2014] UKSC 13, especially [123]-[124].

89 See especially HTC Corp v Nokia Corporation [2013] EWHC 3778 (Pat).

90 Evalve Inc v Edwards Lifesciences Limited [2020] EWHC 513 (Pat).

91 That aspect handed down in [2020] EWHC 514 (Pat).

92 Evalve Inc v Edwards Lifesciences Limited (n 90) [46]-[47]. 
Organon Teknika. ${ }^{93}$ Where 'various public interests are engaged and pull in different directions, one should have in mind that the legislator is better equipped than the courts to examine these issues and draw the appropriate broad balance. 94 On the facts, the public interest in freedom of clinical decision-making did not rise to the level that an injunction would be refused. ${ }^{95}$ But drawing from the analysis of Birss J, one can imagine some compelling arguments that, during a pandemic, the public interest in education is such that access to learning materials must be maintained, and that an injunction should not be granted.

Of course, the refusal to grant an injunction does not mean that the educational establishment faces no consequences, as there is still the question of damages in lieu. In Jaggard $v$ Sanyer, it was held that such damages should be calculated by reference to the price that would be accepted by a 'reasonable seller' rather than a 'ransom price'. ${ }^{96}$ This raises the question of how the position of the reasonable seller is determined. This sort of evidentiary question is an issue for damages generally. For instance, it was said in General Tire v Firestone that, when quantifying damages by reference to a licence fee, the principles in the nineteenth-century case of Penn $v$ Jack still apply, such that the rightsholder cannot 'ascribe any fancy sum which he says he might have charged'. ${ }^{97}$ Instead, all that may be claimed is the 'going rate'. ${ }^{98}$ This principle was applied in the successful strike-out application Lilley $v D M G$ Events Limited, in which the litigant-inperson's copyright infringement claim amounted to, he alleged, f798,728,820. ${ }^{99}$ Applying Firestone, the court found the claimant mistaken to assume 'the infringer had to take the [claimant] as he found him and, specifically, had to accept whatever rate of royalty which the [claimant] says he would have charged for a licence covering all the infringing acts'.100

But even if the claimant cannot pluck sums from thin air, to what extent, if at all, can the defendant push back against prices that it believes are excessive (as has been argued repeatedly in relation to the rates charged for licences for e-books and subscription databases)? And can defendants point to COVID to suggest that usual licence fees may need to be adjusted downwards? Firestone suggests that 'the circumstances in which the going rate was paid' are relevant. ${ }^{101}$ Even if the publisher can produce evidence of a market at particular prices, it is obliged to show that the circumstances of those transactions is 'the same as or at least comparable with those in which the [rightsholder]

93 Discussed at n 85 above.

94 Evalve Inc v Edwards Lifesciences Limited (n 90) [73].

95 The reasoning here was that such a lack of choice was inherent in the patent system. This is not to say that there may not be circumstances where that choice needed to be maintained through the refusal to grant an injunction, but they would be limited.

96 Jaggard v Sanyer [1995] 1 WLR 269, 282.

97 General Tire \& Rubber Co v Firestone Tyre \& Rubber Co [1975] 1 WLR 819, 825, citing Penn v Jack (1867) LR 5 Eq 81, 113-114.

98 Ibid 825.

99 Lilley v DMG Events Limited [2014] EWHC 610 (IPEC).

100 Ibid [52]. The court concluded the proper figure was the more modest sum of circa $f^{83:}$ [60]. This story has a fascinating sequel: Mr Lilley sought to have this decision set aside on the grounds of 'treason, fraud and perverting the course of justice': Lilley v Euromoney Institutional Investor plc [2014] EWHC 2364 (Ch), [3]. In subsequent, related litigation against three further publishers (on the same grounds), he accused the sitting judge, Birss J, of apparent bias and asked that he recuse himself. That application was denied, and his claim for $f_{593 m}$ against the defendants dismissed. Despite being issued with an extended civil restraint order and being made bankrupt as a result of this litigation, he issued further proceedings in January 2017 against different defendants, this time for the lesser sum of $£ 335 \mathrm{~m}$ : Lilley $v$ FT Lmited [2017] EWHC 1916 (Ch). He lost.

101 Firestone (n 97) 825. 
and the infringer are assumed to strike their bargain'. ${ }^{102}$ This might suggest that the existence of COVID could limit the relevance of pre-pandemic prices. That said, there are also limits to this analysis. For instance, it has been said that the Firestone assessment cannot amount to what the defendant 'could have afforded to pay'. ${ }^{103}$ In addition, Firestone should not be understood as a judicial discretion to award what is 'just and fair' in the circumstances. It is not an equitable measure but an opportunity for the parties to introduce extrinsic evidence of what the market will bear, should that amount be less than the publisher's expectation.

In sum, it is possible that public interest arguments could have some bearing on the outcome of any copyright litigation arising out of the pandemic. However, we believe that such arguments would be relevant for remedies - and, perhaps, the availability of a defence under fair dealing or another statutory exception - rather than crystallising as a standalone public interest defence.

\section{Other options}

Thus far, we have described the licensing arrangements and exceptions that are most relevant to education, and concluded that the public interest defence - if it still exists in copyright law - does not map onto the particular issues raised by COVID. We have also observed that, while there are latent flexibilities in our existing statutory exceptions, there are ultimately limits to their reach, especially in relation to copying of lengthy extracts and entire works. In this final section, we consider measures that might be particularly relevant for this latter problem: compulsory licensing and the incentivisation of voluntary negotiation through amendment of section 36 of the CDPA.

In its letter to the UK government, Research Libraries UK identified compulsory licensing as a possible solution to challenges caused by COVID. ${ }^{104}$ In its response, the government rejected this suggestion, stating that it would 'remove exclusive rights from right holders' and would likely be contrary to international copyright law. ${ }^{105}$ Although the government did not spell out its reasoning, this statement would seem to reflect the proposition that compulsory licences are only possible under international copyright law where expressly countenanced in an international instrument. ${ }^{106}$ Relevantly for this article, these instances are rare ${ }^{107}$ and do not include education, except for developing countries. ${ }^{108}$ This view of compulsory licensing also assumes that the greater does not include the lesser: that is, that permission for member states to introduce a free exception

102 Ibid.

103 Irvine v Talksport Limited [2003] EWCA Civ 423, [106] (emphasis in original).

104 RLUK letter (n 11).

105 Solloway letter (n 12).

106 See eg Bently et al (n 13) 315 (one reason there are few non-voluntary licences in the UK is that 'the international standards to which the United Kingdom has committed itself are generally incompatible with compulsory licensing'); see also N Caddick, G Davies and G Harbottle, Copinger and Skone James on Copyright (17th edn, Sweet \& Maxwell online resource 2016-) [28-06].

107 Eg Berne Convention, Articles 11 bis(2) (rebroadcasting), 13 (mechanical recording of musical works); Rome Convention, Article 12 (secondary uses of phonograms).

108 Appendix to the Berne Convention. For discussion, see N Ndiaye, 'The Berne Convention and developing countries' (1986) 11 Columbia-VLA Journal of Law and the Arts 47. 
(under which copyright owners receive nothing) does not implicitly enable them to instead enact an exception that is subject to the payment of remuneration. ${ }^{109}$

A number of counter-arguments can be made. First, even if we accept the latter argument, such that compulsory licensing for education cannot be justified by reference to Article 10(2) of Berne (as no mention is made of remuneration), ${ }^{110}$ the UK could instead point to the three-step test in Article 9(2). ${ }^{111}$ Sam Ricketson and Jane Ginsburg seem to treat this as given in International Copyright and Neighbouring Rights. They state, in relation to course packs, that '[s] uch usages are well developed forms of exploitation in many countries, subject to voluntary licensing arrangements or even compulsory licensing schemes that meet the requirements of article 9(2)'. 112 Second, many countries have compulsory licensing regimes outside the express examples in Berne and other international instruments, including for education. ${ }^{113}$ With no objection having been made to these regimes, for instance under World Trade Organization dispute resolution processes, this state practice could be said to reflect consensus that compulsory licensing is compliant with international copyright law. ${ }^{114}$ Finally, the position said to exist at the international level can be contrasted with EU copyright law, where a number of the permitted exceptions in Article 5 of the ISD are subject to the payment of fair compensation, ${ }^{115}$ and the CJEU has pointed to remuneration in considering whether domestic exceptions are compliant with the three-step test as incorporated in Article 5(5). ${ }^{116}$ As such, the UK government may be unduly cautious in suggesting that compulsory licensing for education would conflict with international copyright law.

109 The Rome Convention provides what is arguably the strongest evidence of a demarcation between free and remunerated exceptions. In Article 15(2), Rome permits contracting states to enact 'the same kinds of limitations' for performances, phonograms and broadcasts as it does for copyright in literary and artistic works, but that 'compulsory licences' may only be granted 'to the extent to which they are compatible with this Convention'. Only one provision - Article 12 - refers expressly to the payment of equitable remuneration. Rome also countenances certain 'exceptions' in Article 15(1).

110 Article 10(2) allows member states 'to permit the utilization, to the extent justified by the purpose, of literary or artistic works by way of illustration in publications, broadcasts or sound or visual recordings for teaching, provided such utilization is compatible with fair practice'. See P Goldstein and B Hugenholtz, International Copyright: Principles, Law, and Practice (3rd edn, Oxford University Press 2013) \$11.1 (describing Article 10(2) as an 'uncompensated limitation').

111 Article 9(2) states: 'It shall be a matter for legislation in the countries of the Union to permit the reproduction of such works in certain special cases, provided that such reproduction does not conflict with a normal exploitation of the work and does not unreasonably prejudice the legitimate interests of the author.'

112 Ricketson and Ginsburg (n 1) [13.45]. In their discussion of the legislative history of Article 9(2), Ricketson and Ginsburg argue at [13.25] that the provision was 'envisaged' to cover free exceptions and compulsory licences and that this makes sense given its purpose and language; that Article 9(2) was intended to apply in a range of 'certain special cases'; and that states were not precluded from tying reliance on an exception to the payment of remuneration.

113 Eg Australian Copyright Act 1968 (Cth), Part IVA, Division 4; Singapore Copyright Act (chapter 63, revised edition 2006), section 52.

114 See Vienna Convention on the Law of Treaties, Article 31(3)(b) (subsequent practice can be used as an aid in treaty interpretation).

115 ISD, Articles 5(2)(a), (b) and (e). An entitlement to receive fair compensation is also found in the EU orphaned works exception: Directive 2012/28/EU of the European Parliament and of the Council of 25 October 2012 on certain permitted uses of orphan works, Article 6(5). In the UK, this amount is to be agreed between the parties or, if no such agreement can be reached, set by the Copyright Tribunal: CDPA, Schedule ZA1, paragraph 7(4). The mandatory exception for uses for the 'sole purpose of illustration for teaching' in the DSM Directive may be implemented as a remunerated exception: Article 5(4).

116 Eg Technische Universitat Darmstadt v Eugen Ulmer KG (n 60) [48]. 
There may nevertheless be philosophical and practical objections to compulsory licensing. The philosophical objection is that compulsory licences are antithetical to private property rights as they remove from individual copyright owners the ability to decide whether to licence rights and for how much. ${ }^{117}$ This might be seen as problematic for a number of reasons: first, because it erodes the decision-making autonomy of owners; and second, because it is likely to lead to inefficient outcomes, on the basis that the state is poorly placed to set prices. ${ }^{118}$ This latter concern will be particularly acute for those who favour neoliberal economic models, the central tenet of which is the supremacy of the market and limiting state interventions. One answer might be that, even if we normally prefer to leave the exploitation of copyright works to voluntary negotiation, a pandemic creates conditions where the usual reasons for market failure holdout, fragmentation of rights, transaction costs, etc - are magnified and of far greater consequence. In universities, for example, access to physical library collections is likely to be limited for some time, making staff and students incredibly reliant on online and digitised content. Even if we ordinarily have an aversion to compulsory licensing, a pandemic may create an environment in which we cannot trust the market to support the required expansion of online collections, making state intervention essential.

But even if those arguments are compelling, there remains the question of whether it is realistic to expect the UK government to have the legislative bandwidth to develop a compulsory licensing regime from scratch, and whether the relevant copyright collectives would be able to implement that scheme in a timely manner. On the plus side, there are already workflows for reporting what has been copied and for the payment and distribution of fees. But before these could be adapted to any new scheme, the government would need to consider many important questions about the terms of the licence. One option might be for the government to develop a broad framework for the licence, on the basis that the precise details in relation to quantitative limits, pricing, reporting, and so forth would be agreed by the relevant parties or, if agreement could not be reached, set by the Copyright Tribunal. If it was attracted to this model, the government could use as a guide the simplified educational copying licence introduced in Australia to replace the schemes in Parts VA and VB. ${ }^{119}$ But while this may speed up the legislative process at the government's end, it would risk generating a protracted commercial negotiation which in all likelihood would end up at the Tribunal. ${ }^{120}$ To avoid such an outcome, the government could finalise many of the details itself, including how remuneration is calculated. But this would only magnify the concern, noted above, that

117 To use the economic language, this changes the copyright owner's entitlement from a property right to a liability rule: see G Calabresi and A Melamed, 'Property rules, liability rules, and inalienability: one view of the cathedral' (1972) 85 Harvard Law Review 1089. Similar objections have been made to the granting of damages in lieu of an injunction, as discussed above in Section 3.2.

118 Concerns about the deficiencies of state decision-making may be even stronger when the royalty is prescribed by statute (statutory licensing) rather than fixed by a tribunal, if a tribunal is better equipped than a legislative drafting team to respond to the views and evidence of relevant stakeholders.

119 Introduced by the Copyright Amendment (Disability Access and Other Measures) Act 2017. For instance, section $113 \mathrm{P}(1)$ sets out the circumstances in which the copying or communicating of a work is noninfringing. These include that a 'remuneration notice' applies and is in force; the act is solely for the educational purposes of that or another educational institution; and that 'the amount of the work copied or communicated does not unreasonably prejudice the legitimate interests of the owner of the copyright'.

120 In Australia, the Copyright Agency Limited and Universities Australia were unable to reach agreement on the methodology for ascertaining the amount of equitable remuneration under a new licence covering the period 1 January 2019 to 31 December 2024. In late 2018, the Copyright Agency made an application to the Copyright Tribunal to determine this point. Interim orders were made by Perram J in May 2019: Copyright Agency Limited v University of Adelaide (Interim Orders) [2019] ACopy'T 2. The matter continues. 
states are not good at setting prices. That is, if the government will do a bad job at a compulsory licence at the best of times, it can hardly be expected to improve on its usual performance during pandemic conditions. Even for those whose views on state intervention are more charitable, one can imagine the concern that a hastily assembled scheme might be either useless to universities or damage the markets and income streams of authors and publishers.

We wonder, though, whether there is a government intervention that would incentivise rather than replace voluntary negotiation: reform of section 36 of the CDPA, perhaps for a limited period, so that it expressly allows educational establishments to copy lengthier extracts or even entire works (perhaps under CDL terms) but not where licences are available that authorise those acts. ${ }^{121}$ To understand this suggestion, it is necessary to step back a moment to understand the structure and goals of section 36. That provision allows educational establishments to copy and communicate, for the purposes of instruction, not more than 5 per cent of a work (not being a broadcast or artistic work). However, section 36 does not apply to the extent that a licence is available and the establishment is aware or ought to have been aware of that fact. ${ }^{122}$ The idea is to simultaneously strengthen the hand of educational establishments at the negotiating table (as they know that they can copy certain amounts for free) and encourage copyright owners to offer licences that go beyond that which is covered by section 36.123 Similar thinking underpinned the recommendation of the Whitford Committee in the 1970s in relation to photocopying by libraries, educational establishments, and so forth. ${ }^{124}$ That committee saw blanket licensing as the best mechanism to deal with reprographic reproduction and recommended the removal of exceptions in the Copyright Act 1956. However, it also observed that users should not be asked to give up these exceptions 'without a guarantee that their needs will be met by blanket licensing schemes'. ${ }^{125}$ The answer of the committee was that a time be set for such negotiations, after which, if licences were not in place, there would be a 'free-for-all' in which copies could be made without payment. ${ }^{126}$ The Whitford Committee saw a number of benefits of this approach, including that the collectives administering the licences would have the flexibility to make different arrangements with different users. ${ }^{127}$

There are many different ways this general idea - of using an exception to incentivise licensing - could be operationalised, and articulation of a detailed plan is beyond the scope of this article. But, to provide a brief example, let us say that the aim is to encourage the expansion of collective licences for published print material so that lengthier extracts and entire works may be copied and made available to staff and students. We might start from the premise that, when it comes to facilitating digitisation,

121 See generally R Merges, 'Contracting into liability rules' (1996) 84 California Law Review 1293, arguing against the widespread use of compulsory licences, noting the efficiency of collective forms of administration and considering various ways to encourage such 'private liability rules' to emerge. For Merges, one way to encourage the latter is to 'modify property rule entitlements so as to increase slightly the risk that the [defendant] can escape entirely from the [claimant's] property right': at 1316.

122 CDPA, section 36(6). It is important to bear in mind that the Copyright Tribunal has ultimate oversight of this process through its supervision of licensing schemes and bodies: see CDPA, chapter VII.

123 It has been questioned whether section 36 achieved this, at least in earlier iterations: R Burrell and A Coleman, Copyright Exceptions: The Digital Impact (Cambridge University Press 2005) 128-129.

124 Whitford Report (n 1).

125 Ibid [279].

126 Ibid.

127 Ibid [280]. 
voluntary licensing - perhaps including a scheme for licensed digital lending - is the gold standard. There are a number of reasons for this. A licensing scheme can permit levels of access beyond those possible under CDL and could conceivably apply to a broader range of works. It avoids some of the uncertainties that are inherent in relying on exceptions, for instance in relation to the right to digitise and the legality of providing access to students located overseas. Depending on how the scheme was set up, universities may be able to access born-digital content or scans produced by other establishments (including, potentially, the British Library), rather than having to digitise everything themselves. Such digital content could include functionality to make it more user-friendly than a pdf of a book and could be accompanied by less aggressive digital rights management (DRM) overlays, to the extent licensed digital lending was permitted. Finally, there could be different approaches to pricing, ranging from transactional fees (whether based on pages, chapters or works) to a subscription-based 'all you can eat' model.

If the government agreed that such an expansion of collective licensing were desirable, it could consider a Whitford-esque approach in which it extends section 36 to cover a greater range of acts. At this point the government would need to think carefully about the details of this reform, as the goal would be to encourage a negotiated solution and not provide educational establishments with such an attractive exception that licensing becomes redundant. ${ }^{128}$ But we can imagine that its response might comprise or include an exception that explicitly allowed educational establishments to adopt CDL. That exception would need to follow the key features of CDL, for instance in relation to the owned-to-loaned ratio and the inclusion of DRM to limit re-use by the borrower. It would permit educational establishments to copy entire works, although we can envisage a key area of debate being whether any published work held in physical form could be copied in full, or whether there would be different rules for titles that are also available commercially in digital form. Allowing such books to be digitised in full would raise complaints about market substitution. On the other hand, one might ask why universities should be asked to pay over and over again for the same content. If a university acquires, lawfully, a physical book and wishes to digitise that book and lend a soft copy under strict CDL terms, why should we protect the e-book market?

In suggesting the expansion of section 36, we do not mean to imply that this would be a straightforward or easy option for the UK government to operationalise. But we believe that the sort of consultation and review required for an exception would be of a much lower magnitude than that required for a fully fledged compulsory licensing system. Being unremunerated, there would be no need to set a price. The general idea would be to give universities greater comfort in embracing CDL than can be achieved from section 32 and $36 \mathrm{~A}$ alone, but in the context where a collective licence and/or licensed digital lending scheme would be even better.

\section{Conclusion}

As stated in the introduction, the COVID-19 pandemic has not generated entirely new problems for educational institutions in relation to copyright but has magnified the effects of longstanding tensions and issues. We have made a number of suggestions for how universities may make better use of exceptions and have suggested that, if the government is minded to intervene, the best approach may be to encourage voluntary licensing. But, for universities and their representatives at the negotiating table right now,

128 Indeed, such an exception may be inconsistent with the three-step test as found in Article 5(5) of the ISD and various international treaties. 
what can they do to ensure the economic realities of teaching during a pandemic figure in their discussions with rightsholders? As a matter of law, it is very important to hold the line in relation to exceptions, and we have also discussed whether public interest arguments might be relevant to remedies. But, beyond that, we see the negotiation as largely commercial in nature. Even before the pandemic, there were ongoing complaints that publishers were insisting on high, unrealistic prices for digital content. We would suggest that, before publishers get too strident in their insistence that everything should be left to private ordering and that this is just the way of things, they may want to reflect on one form of private ordering that universities might, following COVID, be even more minded to embrace. This crisis illustrates both the fragility of the university's position and their dependence upon the goodwill of publishers. It only heightens the urgency of considering new publishing models, given the preponderance of materials hawked about by publishers that emanate from the efforts of employees in the university sector. Is it not, then, time for the university sector to move even more aggressively towards open access and other in-house publishing models, so that we have greater control over our own destiny and can reap the benefits ourselves? 